\title{
Radon potential mapping in Piemonte (North-West Italy): An experimental approach
}

\author{
E. Chiaberto, M. Magnoni, E. Serena, S. Procopio,
}

A. Prandstatter and F. Righino

ARPA Piemonte, Dipartimento Radiazioni - Via Jervis, 30

10015 Ivrea (TO), Italy

\section{Introduction}

Early radon studies in Piemonte, an administrative district in North-West Italy $\left(25200 \mathrm{~km}^{-2}\right.$, around 4300000 inhabitants) have been done since 19901991, when a general radon survey of the dwellings of Piemonte was performed in order to assess the average radon exposure of the whole population. The survey, executed in the framework of the National Radon Survey by the National Environmental Protection Agency (former ANPA, now ISPRA) and ISS (National Health Institute), involved about 430 dwellings, chosen randomly with a stratified sampling technique.

After this first step, radon researches were continued in different areas of Piemonte and involved schools as well as dwellings.

In particular, radon surveys were conducted in areas where the geological conditions (i.e., the occurrence of rocks with Uranium content well above the typical average concentration found in the Earth crust) appear to favour a stronger radon emanation. Besides this kind of studies, other surveys were performed in order to assess the radon exposure in schools, where children and young students, the most radio-sensitive part of the population could be exposed to high radon concentrations.

These extensive radon monitoring programs led to the implementation of

This is an Open Access article distributed under the terms of the Creative Commons Attribution License 2.0, which permits unrestricted use, distribution, and reproduction in any medium, provided the original work is properly cited. 
a large radon database of more than 3500 radon measurements distributed all over the Piemonte Region. The whole radon database, before being used as a tool for the definition of the radon prone areas of Piemonte, was subject to a careful analysis and selection, in order to eliminate not representative measurements. In particular, to minimize a possible bias due to the wellknown radon fluctuations both on daily and seasonal basis, we considered only long term measurements (annual), performed using the nuclear track etch detectors technique (LR 115 or CR-39).

The radon potential mapping of the whole Piemonte was then achieved developing a "geolithological correlation model", based on a statistical analysis of the radon experimental data and the underlying geological, lithological and radiometric characteristics of soils and rocks.

\section{Material and methods}

The well-known phenomenon of the fluctuation of indoor radon concentrations both on daily and seasonal basis is probably the most important factor to be taken into account in order to harmonize a radon database. In fact, grab sampling measurements and short-term measurements (i.e., lasting a few days) often give results very different from long-term measurements, that are considered much more reliable, especially for radon mapping purposes. Therefore, for each sampling site, we decided to consider only those measurements able to give the annual average radon concentration.

Moreover, in order to minimize possible calibration and measurement procedure bias, we decided to include only the measurements performed with the same technique, based on a dosimeter equipped with standard nuclear track etch detectors (LR 115 or CR-39). In this way, the original database was resized to about 2400 measurements.

In order to reduce the heterogeneity of the sample, due in particular to the floor where the dosimeters were installed (fig. 1), a ground floor normalization of the data referred to higher floors was performed and validated (fig. 2).

Assuming that the distribution of the indoor radon concentration at ground floor is approximately lognormal, the normalization was done as follows:

$$
f\left(C_{G F}\right)=\frac{1}{\sqrt{2 \pi} \sigma_{G F}} \frac{e^{-\frac{\left(\ln \left(C_{G F}\right)-\mu_{G F}\right)^{2}}{2 \sigma_{G F}{ }^{2}}}}{C_{G F}}
$$

with $\mu_{G F}=\ln \left(G M_{G F}\right), \sigma_{G F}=\ln \left(G S D_{G F}\right)$, the $G M_{G F}$ and $G S D_{G F}$ being 


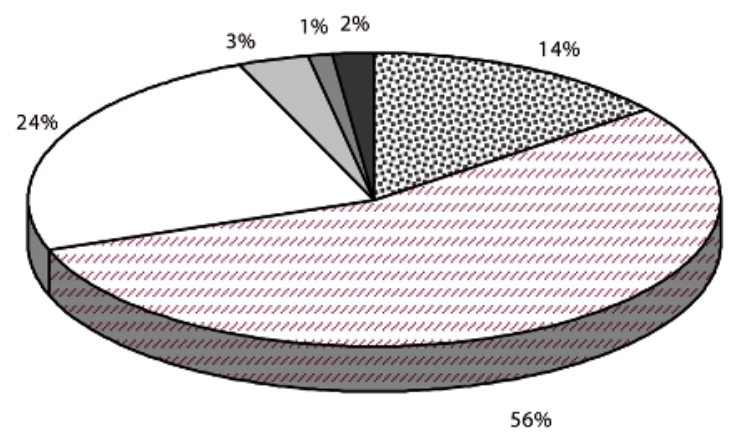

因basement

Qground floor $\square$ first floor

$\square$ second floor

$\square$ third floor

aother floors

Figure 1: Radon measurements available in our database: $56 \%$ were performed at ground floor.

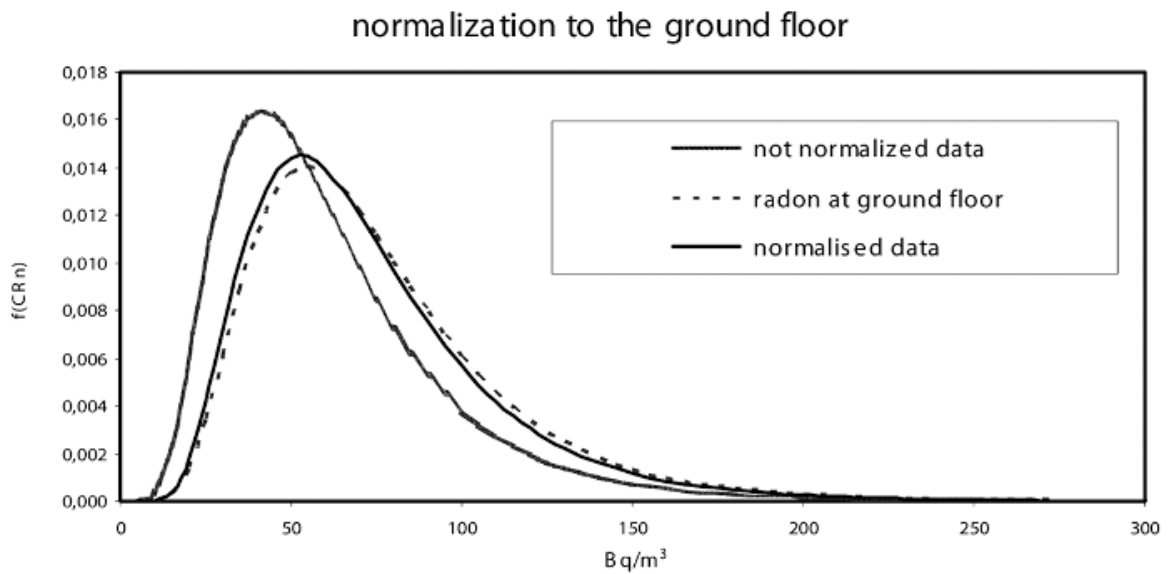

Figure 2: Normalization to ground floor. 


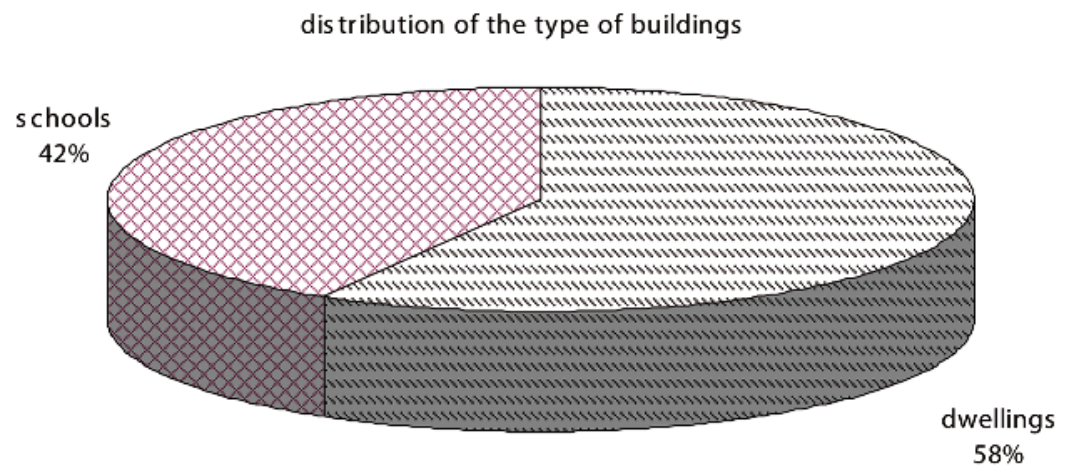

Figure 3: Schools represent $42 \%$ of the whole radon database.

the geometric mean and geometric standard deviation. If we suppose that, in any given dwelling, a linear relationship holds between the radon concentration at ground floor $\left(C_{G F}\right)$ and the radon concentration $C_{F}$ at a generic floor F, i.e.:

$$
C_{F}=k C_{G F},
$$

where $k$ is a constant to be determined, the radon distribution at generic floor $F$ can be written as follows:

$$
f\left(C_{F}\right)=\frac{1}{\sqrt{2 \pi} \sigma_{F}} \frac{e^{-\frac{\left(\log \left(C_{F}\right)-\mu_{F}\right)^{2}}{2 \sigma_{F}^{2}}}}{C_{F}},
$$

\section{Schools - dwellings normalization}

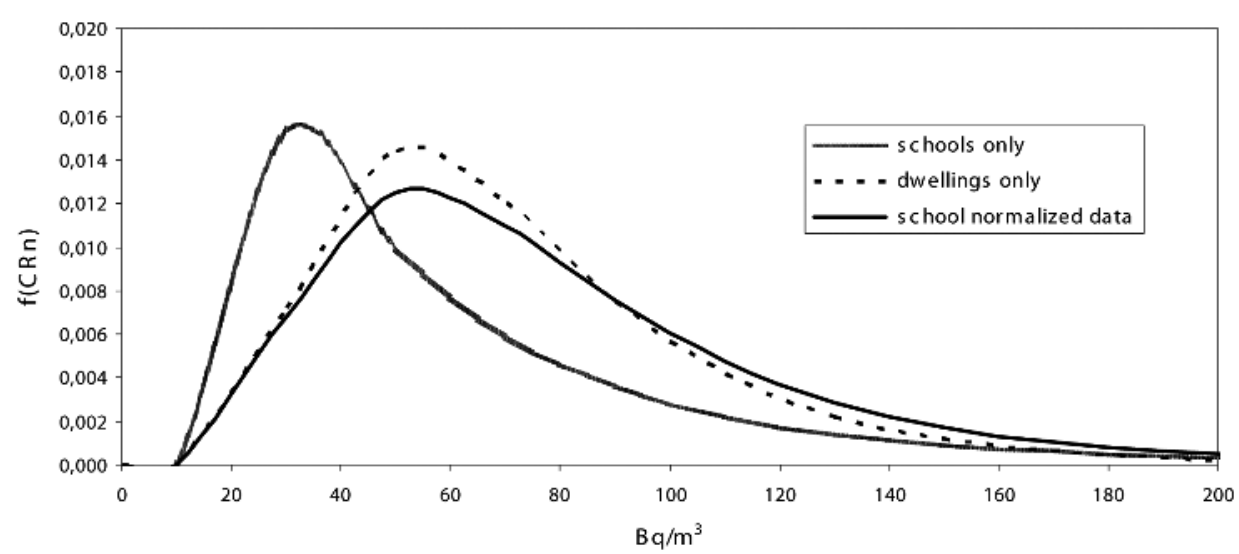

Figure 4: Normalization from schools to dwellings. 


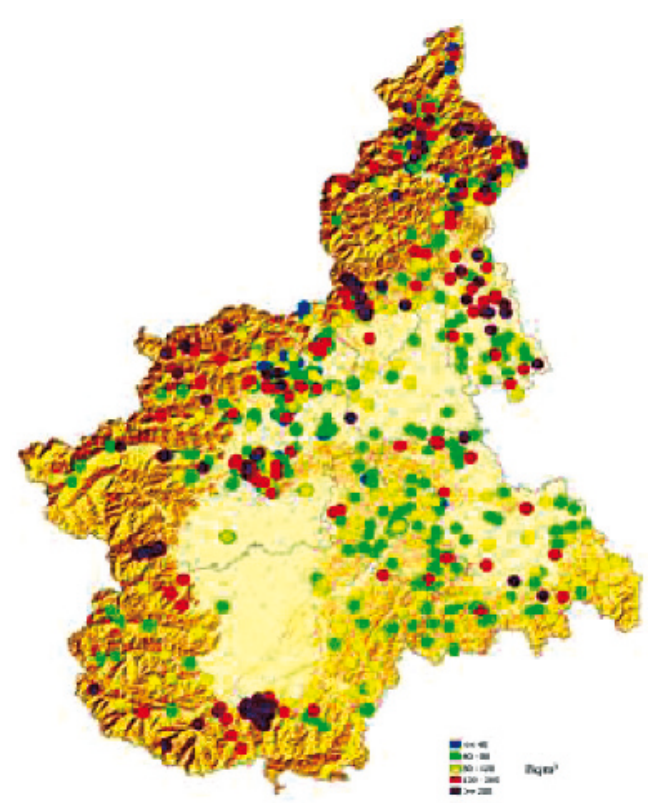

Figure 5: The radon experimental data (normalized to ground floor).

where $\mu_{F}=\ln k+\mu_{G F}, \sigma_{F}=\sigma_{G F}$ and $k$ is given by $k=\frac{e^{\mu_{F}}}{e^{\mu_{G F}}}$.

In order to include also the measurements performed in schools that represent the $42 \%$ of the whole database (fig. 3), another normalization is needed. In fact, because of the different constructive characteristics, the radon concentration in typical school buildings is generally lower than those in dwellings. Therefore, the "school concentrations" were normalized to "dwelling concentrations": $C_{\text {dwellings }}=C_{\text {schools }}+\Delta C$, where $\Delta C=$ $G M_{\text {dwellings }}-G M_{\text {schools }}$ (fig. 4).

Once obtained a global ground floor normalized database, the following step was the definition of the basic criteria of the radon potential mapping. First of all it was decided to consider a subdivision of the Region in 1206 administrative units, corresponding to the municipality of Piemonte. It was then defined, as radon potential indicator, the mean of the radon concentration measurements performed at ground floor and the related log-normal distribution. Unfortunately, being the number of municipality of Piemonte very large (1206), the actual database cannot give a representative sample for each administrative district. In fact, only in the municipality where the number of valid measurements were greater than 4 , the mean and the related log-normal distribution was experimentally obtained. Therefore, in order to attribute an appropriate mean radon concentration value and a 


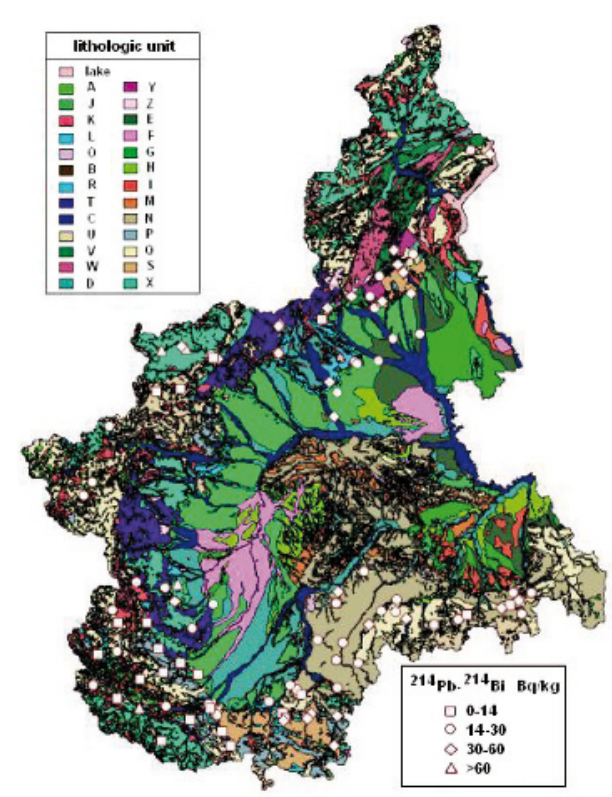

Figure 6: Lithological and radiometric characteristics of soils and rocks.

reliable log-normal distribution to all the administrative districts, we had to estimate these quantities for the municipalities where the experimental data are lacking. So, a "geolithological correlation model" was developed, based on a statistical analysis of the radon experimental data (fig. 5) and the underlying geological, lithological (fig. 6) and radiometric characteristics of the soils and rocks.

An ad hoc subdivision of the Region in lithological-radiometric units was performed taking into account also for the results of the analysis of a wide measurement campaign ( $\gamma$ spectrometry) of the natural radioactivity (mainly due to uranium) in the soils and the rocks of Piemonte.

In table I are reported the data of ${ }^{214} \mathrm{~Pb}$ and ${ }^{214} \mathrm{Bi}$, the natural radioisotopes belonging to the uranium series that, being the short lived radon daughters, can be regarded as good indicators of the potential radon emanation.

The rocks were then classified in four different categories, accordingly with their radioactivity content (average values of ${ }^{214} \mathrm{~Pb}$ and ${ }^{214} \mathrm{Bi}$ ):

very low radioactivity $(<14 \mathrm{~Bq} / \mathrm{kg})$

low radioactivity $(14 \mathrm{~Bq} / \mathrm{kg}-30 \mathrm{~Bq} / \mathrm{kg})$

high radioactivity $(30 \mathrm{~Bq} / \mathrm{kg}-60 \mathrm{~Bq} / \mathrm{kg})$

very high radioactivity $(>60 \mathrm{~Bq} / \mathrm{kg})$. 
Table I: $\gamma$-spectrometry measurements (HPGe) in various types of soils and rocks $\left({ }^{214} \mathrm{~Pb} \mathrm{e}{ }^{214} \mathrm{Bi}\right)$.

\begin{tabular}{|c|c|c|c|}
\hline Soil & Locality & $\begin{array}{l}{ }^{214} \mathrm{~Pb} \\
\left(\mathrm{~Bq} \mathrm{~kg}^{-1}\right)\end{array}$ & $\begin{array}{l}{ }^{214} \mathrm{Bi} \\
\left(\mathrm{Bq} \mathrm{kg}^{-1}\right)\end{array}$ \\
\hline porphyritic granite & Campiglia Cervo & 91.9 & 104.7 \\
\hline augen gneiss & Noasca & 73.4 & 66.6 \\
\hline augen gneiss & Ceresole Reale & 68.0 & 61.8 \\
\hline porphyroid and uranium minerals & Canosio, Preit & 396850 & 359350 \\
\hline porphyroid & Canosio & 8986 & 8096 \\
\hline volcanic rock & Masserano & 62.9 & 56.5 \\
\hline gneiss & Vinadio & 165.5 & 149.7 \\
\hline gneiss & Barge & 96.1 & 83.1 \\
\hline biotitic diorite & Netro & 37.9 & 34.2 \\
\hline alluvial cone gravel & Scopello & 35.9 & 34.4 \\
\hline pebble & Sordevolo & 32.5 & 30.5 \\
\hline sandstone & Roccaverano & 32.8 & 28.6 \\
\hline alluvium & Borgosesia & 35.6 & 32.3 \\
\hline alluvium & Quarona & 42.5 & 40.0 \\
\hline alluvium & Livorno Ferraris & 37.1 & 38.4 \\
\hline alluvium & Saluggia & 38.1 & 35.5 \\
\hline porphyry & Serravalle Sesia & 36.3 & 33.2 \\
\hline calcareous and micaceous schist & Limone Piemonte & 31.5 & 34.4 \\
\hline orthogneiss & Pamparato & 29.9 & 33.9 \\
\hline micaschist & Pamparato & 28.5 & 31.6 \\
\hline micaceous quartz schist & Pamparato & 52.0 & 48.3 \\
\hline quartz porphyry & Frabosa Soprana & 37.6 & 37.9 \\
\hline albite gneiss & Locana & 61.7 & 57.2 \\
\hline pink granite & Vidracco & 48.0 & 44.8 \\
\hline augen gneiss & Noasca & 46.3 & 42.6 \\
\hline silty marl & Tornese & 39.5 & 35.8 \\
\hline polygenic conglomerates & Bagnasco & 33.4 & 31.0 \\
\hline quartz schist & Garessio & 38.6 & 33.9 \\
\hline clay marl & Cortemilia & 34.4 & 30.2 \\
\hline clay marl & Diano d' Alba & 31.5 & 29.3 \\
\hline marl & Alba & 44.1 & 40.6 \\
\hline serpentinite & Vidracco & 60.4 & 55.0 \\
\hline diorite & Traversella & 39.9 & 35.3 \\
\hline biotitic gneiss & Traversella & 58.7 & 51.7 \\
\hline silty marl & Carrosio & 37.5 & 25.9 \\
\hline schist \gneiss & Cannobio & 37.5 & 32.9 \\
\hline silty marl & Tornese & 37.0 & 29.3 \\
\hline gneiss & San Front & 35.1 & 28.7 \\
\hline marl & Castagnole delle Lanze & 26.4 & 24.4 \\
\hline sandstone & Vesime & 24.0 & 22.9 \\
\hline clay marl & Monastero Bormida & 24.8 & 28.7 \\
\hline
\end{tabular}


EPJ Web of Conferences

Table I: Continued.

\begin{tabular}{|c|c|c|c|}
\hline granite & Valle San Nicolao & 20.0 & 22.2 \\
\hline biotite micaschist & Valduggia & 24.1 & 26.1 \\
\hline clay marl & Bubbio & 26.7 & 24.1 \\
\hline biotic granite & Pray & 30.8 & 29.1 \\
\hline black clay & Cavaglià & 27.7 & 24.2 \\
\hline clay & Cavaglià & 21.7 & 22.0 \\
\hline alluvium & Carisio & 21.3 & 19.4 \\
\hline alluvium & Bronzo & 17.5 & 16.1 \\
\hline fluvioglacial gravel & Arborio & 30.6 & 27.4 \\
\hline reddish paleosol & Cigliano & 15.9 & 16.7 \\
\hline quartz porphyry & Brusnengo & 25.2 & 25.0 \\
\hline quartz schist & Robilante & 27.9 & 25.7 \\
\hline quartz schist & Robilante & 26.5 & 24.9 \\
\hline chlorite-bearing granite & Valdieri & 17.8 & 19.7 \\
\hline calcareous and micaceous schist & Borgo San Dalmazzo & 23.4 & 22.0 \\
\hline ottrelite schist & Frabosa Sottana & 23.3 & 21.8 \\
\hline marly sandstone & Vicoforte di Mondovì & 21.8 & 24.8 \\
\hline marly sandstone & Vicoforte di Mondovì & 28.1 & 26.6 \\
\hline sandy marl & Mondovì & 19.7 & 17.6 \\
\hline dolomitic limestone & Villanova di Nondovì & 25.0 & 27.2 \\
\hline micaschist & Frabosa Soprana & 20.1 & 19.2 \\
\hline amphibolite & Locana & 20.2 & 18.3 \\
\hline silty marl & Arquata Scrivia & 28.3 & 24.7 \\
\hline clay marl & Grondona & 30.8 & 29.0 \\
\hline silt & Gavi & 25.8 & 23.8 \\
\hline silty marl & Ponzone & 27.1 & 25.0 \\
\hline dolomite and limestone & Voltaggio & 25.3 & 22.2 \\
\hline silty marl and silt & Cassinelle & 27.6 & 24.5 \\
\hline sandstone & Dogliani & 19.8 & 18.2 \\
\hline gray marl & Murazzano & 27.9 & 25.6 \\
\hline gray sandstone & Murazzano & 15.6 & 14.3 \\
\hline yellow sand & Murazzano & 19.6 & 16.9 \\
\hline gray sandstone & Bossolasco & 17.2 & 15.6 \\
\hline grey sand & Bossolasco & 21.1 & 20.4 \\
\hline sandstone & Cortemilia & 21.3 & 19.0 \\
\hline marl & Ceva & 29.0 & 25.5 \\
\hline sandstone & Monesiglio & 18.7 & 17.5 \\
\hline grey marl & Monesiglio & 18.3 & 16.9 \\
\hline yellow sand & Diano d' Alba & 19.7 & 17.5 \\
\hline fine-grained gneiss (Gneiss minuti complex) & Cavaglio Spoccia & 30.3 & 25.7 \\
\hline silty marl, silt and sandstone & Arquata Scrivia & 30.9 & 23.5 \\
\hline silty marl & Cassinelle & 20.0 & 17.3 \\
\hline dolomite and limestone & Voltaggio & 23.8 & 22.3 \\
\hline sandy marl, silt and sandstone & Ponzone & 17.8 & 15.4 \\
\hline
\end{tabular}


Table I: Continued.

\begin{tabular}{|c|c|c|c|}
\hline silt and sandstone & Gavi & 19.3 & 13.1 \\
\hline calcareous schist & Pragelato & 29.1 & 25.8 \\
\hline calcareous schist & Novalesa & 31.4 & 26.1 \\
\hline calcareous schist & Sestriere & 27.1 & 19.8 \\
\hline gneiss \micaschist & Venasca & 22.3 & 20.6 \\
\hline gneiss \micaschist & Saluzzo & 32.0 & 26.2 \\
\hline marble & Argentera & 23.6 & 21.2 \\
\hline calcareous schist & Pontechianale & 18.7 & 16.3 \\
\hline calcareous schist & Capoluogo & 30.1 & 24.9 \\
\hline phyllitic carbonate schist & Prazzo & 18.9 & 16.6 \\
\hline gneiss $\backslash$ micaschist & Paesana & 22.2 & 11.9 \\
\hline gneiss & Demonte & 18.2 & 15.5 \\
\hline melanocratic diorite & Netro & 2.0 & 2.4 \\
\hline dolomitic limestone & Borgo S. Dalmazzo & 6.0 & 6.6 \\
\hline micaceous limestone & Limone Piemonte & 10.9 & 10.3 \\
\hline micaceous limestone & Roccavione & 3.7 & 4.3 \\
\hline biotite gneiss & Valdieri & 13.8 & 13.3 \\
\hline quartzite & Frabosa Sottana & 12.6 & 13.9 \\
\hline dolomitic limestone & Vernante & 12.9 & 12.8 \\
\hline limestone & Valdieri & 5.4 & 5.3 \\
\hline sandy conglomerate & Vicoforte & 11.6 & 10.4 \\
\hline quartz conglomerate & Frabosa Soprana & 7.4 & 7.0 \\
\hline quartzite sandstone & Frabosa Soprana & 6.5 & 5.6 \\
\hline amphibolite & Locana & 0.8 & 0.3 \\
\hline pyroxenite & Balme & 1.4 & 1.2 \\
\hline serpentine schist & Ala di Stura & 0.3 & 0.3 \\
\hline silty marl, sandstone and silt & Carrossio & 14.6 & 12.6 \\
\hline calcarenite & Bosio & 14.2 & 13.0 \\
\hline sandstone, sandy marl, silt & Molare & 10.3 & 9.4 \\
\hline sandstone & Diano d'Alba & 13.2 & 12.5 \\
\hline sandstone & Molare & 11.9 & 10.6 \\
\hline polygenic conglomerate & Bosio & 12.7 & 10.9 \\
\hline micaschist & Caraglio & 10.4 & 9.5 \\
\hline gneiss, micaschist & Sampeyre & 9.6 & 8.5 \\
\hline serpentinite & Acceglio & 1.5 & 1.6 \\
\hline marble & Pradleves & 12.9 & 12.6 \\
\hline marble & Sambuco & 3.2 & 2.8 \\
\hline marble & San Damiano Macra & 10.2 & 9.4 \\
\hline serpentinite & Casteldelfino & 0.9 & 1.0 \\
\hline limestone - dolomite breccia & Dronero & 7.1 & 6.3 \\
\hline marble & Castelmagno & 10.1 & 7.7 \\
\hline
\end{tabular}




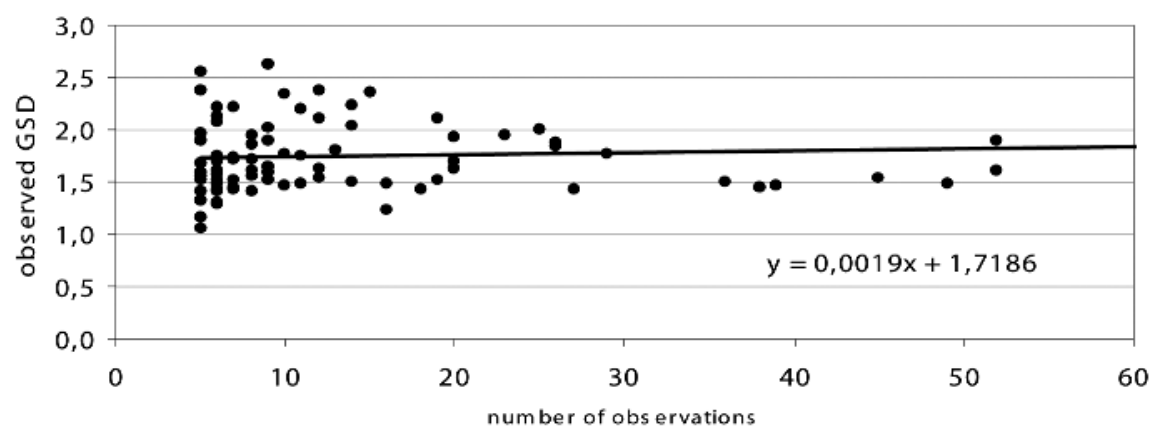

Figure 7: Observed geometric standard deviation.

Taking into account for this information, it was possible to establish a more simple subdivision of the Region in only 26 lithological-radiometric units, instead of the original 44 lithological units (fig. 6). Radon was then evaluated, using the experimental radon concentrations, in each of the new 26 lithological-radiometric units, thus obtaining, for each unit, a "Lithologic Mean" (LM)(table II).

It was then possible to compute the radon concentration mean $A M_{j}$ for the generic $j^{\text {th }}$ municipality in whose area $p$ different lithologicalradiometric units were present:

$$
A M_{j}=\sum_{k=1}^{p} \frac{A L_{k} \cap A C_{j}}{A C_{j}} \cdot L M_{k},
$$

where:

$L M_{k}$ : Rn concentration mean (normalized to ground floor) of the $k^{\text {-th }}$ lithological unit

$A C_{j}$ : surface of the $j^{\text {-th }}$ municipality area

$A L_{k}$ : surface of the $k^{\text {th }}$ lithological unit

The geometric standard deviation (GSD), necessary for the definition of the log-normal distributions, was evaluated considering the asymptotic value of all the experimental GSDs (fig. 7).

This approach was then validated comparing the values predicted by the model with the means experimentally calculated in those municipalities where the data were available (fig. 8). In this analysis, in order to avoid auto-correlation effects, the lithological means used for the model prediction were calculated excluding the data of the municipality where the mean was evaluated from experimental data. 
Table II: Lithological-radiometric units.

\begin{tabular}{|c|c|c|}
\hline $\begin{array}{l}\text { Lito } \\
\text { code }\end{array}$ & New lithologic units & $\begin{array}{c}\mathbf{L M} \\
\mathrm{Bq} \mathrm{m}^{-3}\end{array}$ \\
\hline A & Talus slopes, debris cones and alluvial fans & 129 \\
\hline $\mathrm{B}$ & Peat and swamp deposits of recent lakes & 27 \\
\hline $\mathrm{C}$ & Gravel - recent and present river beds & 159 \\
\hline $\mathrm{D}$ & Terraced gravelly, sandy and silty alluvial deposits & 72 \\
\hline $\mathrm{E}$ & Pebbly coarse sandy and silty alluvial deposits & 85 \\
\hline $\mathrm{F}$ & Predominantly sandy alluvial deposits & 90 \\
\hline G & Mildly weathered silty and sandy alluvial deposits & 98 \\
\hline $\mathrm{H}$ & $\begin{array}{l}\text { Predominantly silty and clayey alluvial deposits with sand-gravelly lenses } \\
\text { and clayey loess; "ferretto" }\end{array}$ & 73 \\
\hline $\mathrm{I}$ & $\begin{array}{l}\text { Alternating reddish gravelly and sandy alluvial deposits and yellow sand } \\
\text { with frequent clay, weathered caolinicclays }\end{array}$ & 133 \\
\hline $\mathrm{J}$ & $\begin{array}{l}\text { Fluvioglacial gravel and pebble alluvial deposits, with large boulders, } \\
\text { weathered forming clay soils ("ferretto") }\end{array}$ & 97 \\
\hline $\mathrm{K}$ & Recent moraines without significant weathering & 149 \\
\hline $\mathrm{L}$ & Moraine deposits with strongly weathered cobbles ("ferretto" weathering) & 82 \\
\hline $\mathrm{M}$ & Silty clay with interbedded sands; marl and clay with sand. Clays & 97 \\
\hline $\mathrm{N}$ & $\begin{array}{l}\text { Sands, coarse sands, with gravel lenses and intercalating to sandstones and } \\
\text { marls, } \\
\text { Poorly cemented calcarenites and calcirudites } \\
\text { Marly calcarenites and marly limestones interbedded with limited lime- } \\
\text { stones, silty marls and sandstones } \\
\text { Polygenic conglomerates, conglomerates and sandstones forming thick lay- } \\
\text { ers with intercalating sandy marls, clay and limestone } \\
\text { Alternating limestones, marly limestones, calcareous sandstones, clays and } \\
\text { marls } \\
\text { Sandy and silty marls and clay marls, marl with alternating sandstones } \\
\text { and limestones, marly limestones and clays }\end{array}$ & 64 \\
\hline $\mathrm{O}$ & $\begin{array}{l}\text { Clays and marly clays with lenses of gypsum and subordinate intercala- } \\
\text { tions of vacuolar limestone, sand or sandstone ("gessoso-solfifera" forma- } \\
\text { tion), } \\
\text { Vacuolar dolomites and vacuolar limestones }\end{array}$ & 75 \\
\hline $\mathrm{P}$ & $\begin{array}{l}\text { Gypsum deposits } \\
\text { Medium-thin layered limestones, marly limestones, cherty limestones } \\
\text { massive or thickly-layered limestones } \\
\text { Dolomite and dolomitic limestones with interbedded graphite-micaschists } \\
\text { and lenses of granite. } \\
\text { Peridotite and lherzolite. } \\
\text { Saccharoid, frequently silicate marbles, dolomitic marbles }\end{array}$ & 123 \\
\hline Q & $\begin{array}{l}\text { Flysch successions and their metamorphic derivates: clays, marls, sand- } \\
\text { stones, limestones, marly limestones; } \\
\text { calcareous schists, micaschist, gneiss, slates }\end{array}$ & 88 \\
\hline $\mathrm{R}$ & $\begin{array}{l}\text { Quartzites, quartzarenites, sandy and conglomeratic quartzites, micaceous } \\
\text { quartzites, quartz schists }\end{array}$ & 82 \\
\hline $\mathrm{S}$ & $\begin{array}{l}\text { Sericitic schists and sericitic quartz schist. Porphyrites and weathered } \\
\text { porphyrites. } \\
\text { Rhyolites, rhyolitic tuffs and agglomerates } \\
\text { Andesites, andesitic tuffs and tuffaceous agglomerates }\end{array}$ & 229 \\
\hline
\end{tabular}


Table II: Continued.

\begin{tabular}{|c|l|c|}
\hline $\mathrm{T}$ & Micaschists gneiss, quartz-micaschists phyllitic micaschists & 169 \\
\hline $\mathrm{U}$ & Amphibolites, serpentinites, prasinites & 129 \\
\hline $\mathrm{V}$ & Kinzigite and amphibolite gneiss, associated augen gneiss & 97 \\
\hline $\mathrm{W}$ & $\begin{array}{l}\text { Basic granulites and associated amphibolites, } \\
\text { melanocratic diorites, diabase and metagabbros }\end{array}$ & 96 \\
$\mathrm{X}$ & $\begin{array}{l}\text { Tabular augen gneiss, with closely spaced joints, fine-grained gneiss, } \\
\text { augen gneiss, massive granitic gneiss with widely spaced joints, porphyroids } \\
\text { White, green, pink massive granite with no cover and weathering. } \\
\text { Aplites and pegmatites }\end{array}$ & 123 \\
\hline $\mathrm{Y}$ & Weathered granites and deriving thick arcosic sands & 62 \\
\hline $\mathrm{Z}$ & Syenite, monzonite, quartzdiorite, granodiorite & 913 \\
\hline
\end{tabular}

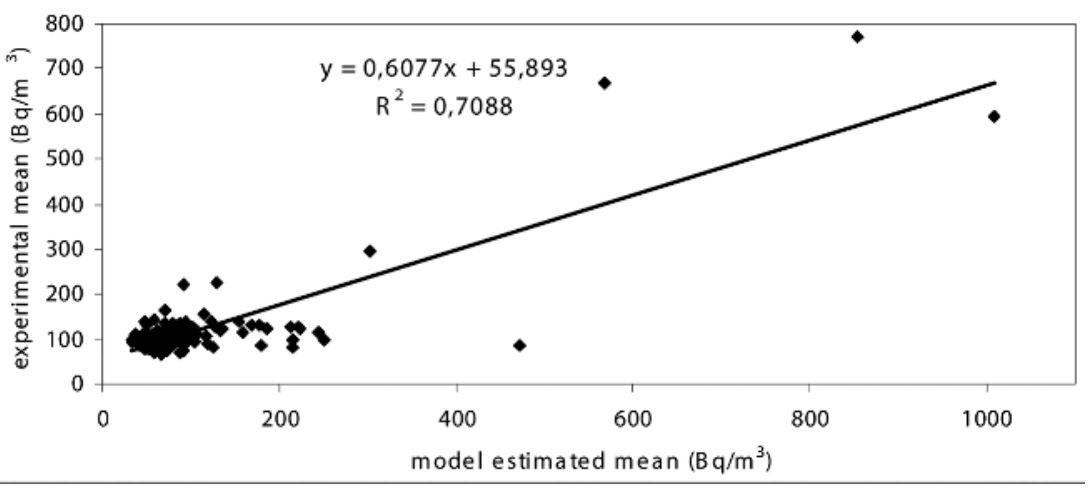

Figure 8: Validation of the model. 
The result obtained in this validation analysis can be considered quite good $\left(R^{2}=0.71\right)$, thus allowing the use of the model for prediction purposes.

\section{Results and discussion}

It is well-known that the experimental data of indoor radon can be considered roughly distributed accordingly to a log-normal function:

$$
f(c)=\frac{e^{\frac{-(\ln c-\mu)^{2}}{2 \sigma^{2}}}}{\sqrt{2 \pi} \cdot \sigma \cdot c}
$$

where

$$
\mu=\frac{1}{n} \sum_{i=1}^{n} \ln \left(c_{i}\right) \quad \sigma=\sqrt{\frac{1}{n-1} \sum_{i=1}^{n}\left[\ln \left(c_{i}\right)-\mu\right]^{2}}
$$

and $c_{i}$ are the experimental values of the radon concentration.

The radon mapping of Piemonte was thus performed defining, for each municipality, the function $f(c)$ reported in eq. (2), whose parameters were calculated in two different ways. For the municipality where experimental data were considered representative, $f(c)$ was defined simply evaluating $\mu$ and $\sigma$ from eq. (3). In the other cases, $\sigma$ was calculated from the extrapolation of the experimental GSDs (see fig. 7), while $\mu$ was calculated from the $A M_{j}$, evaluated by means of eq. (1), taking into account that the arithmetic mean $A M$ of a variable log-normally distributed can be expressed as follows:

$$
A M=\int_{0}^{\infty} \frac{e^{\frac{-(\ln x-\mu)^{2}}{2 \sigma^{2}}}}{\sqrt{2 \pi} \cdot \sigma} \mathrm{d} x=e^{\mu+\frac{\sigma^{2}}{2}} .
$$

From the log-normal distributions, can also be calculated, in each sampling unit, the percentage of dwellings that exceed a given reference level $R_{L}$.

$$
P_{\% R L}=100 \cdot \int_{R_{L}}^{\infty} \frac{e^{\frac{-(\ln c-\mu)^{2}}{2 \sigma^{2}}}}{\sqrt{2 \pi} \cdot \sigma \cdot c} \mathrm{~d} c .
$$

In fig. 9 the results of the calculation of eq. (5) for the whole Region are reported. It can be seen that about $2 \%$ of the dwellings of Piemonte exceed the European Reference level of $200 \mathrm{~Bq} \mathrm{~m}^{-3}$.

In fig. 10 the map displaying the radon concentration $A M$ for each municipality of Piemonte is reported. 


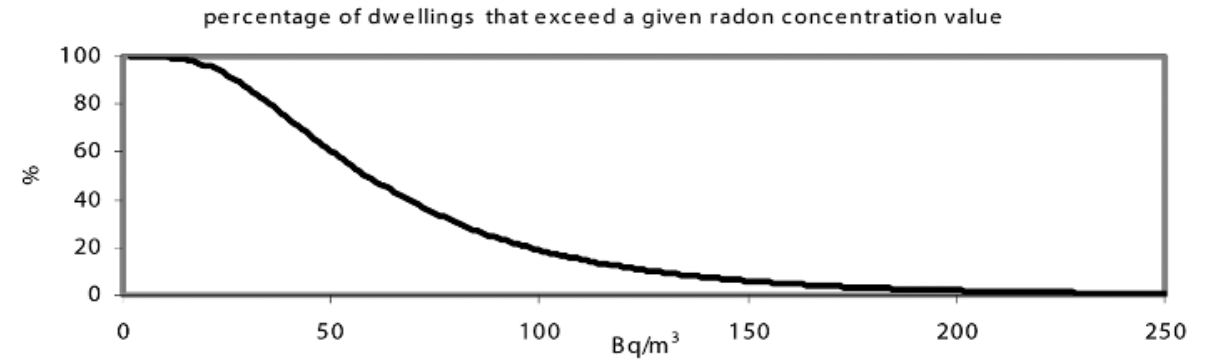

Figure 9: Estimation, by means of eq. (5) of the percentage of the dwellings of Piemonte exceeding a given radon concentration value (ground floor).

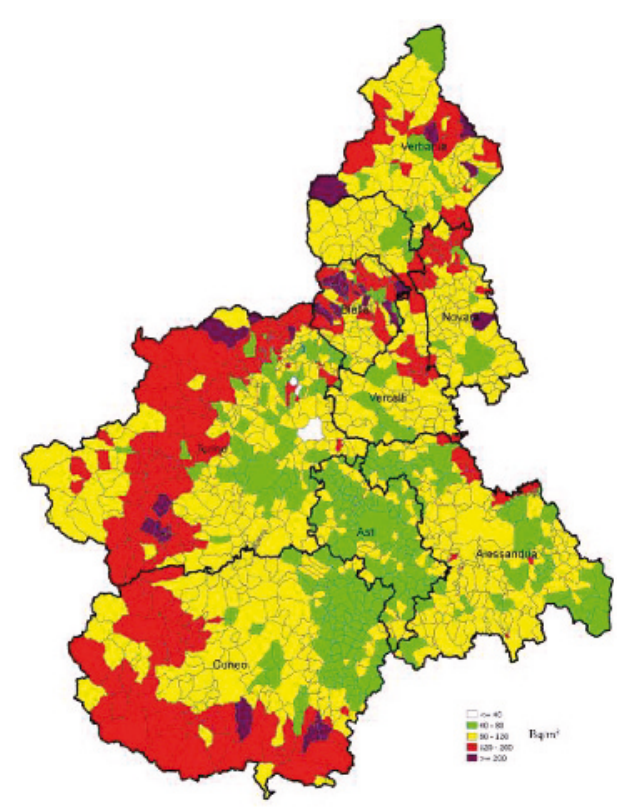

Figure 10: Average values in the municipalities of Piemonte - ground floor concentration $\left(\mathrm{Bq} \mathrm{m}^{-3}\right)$. 


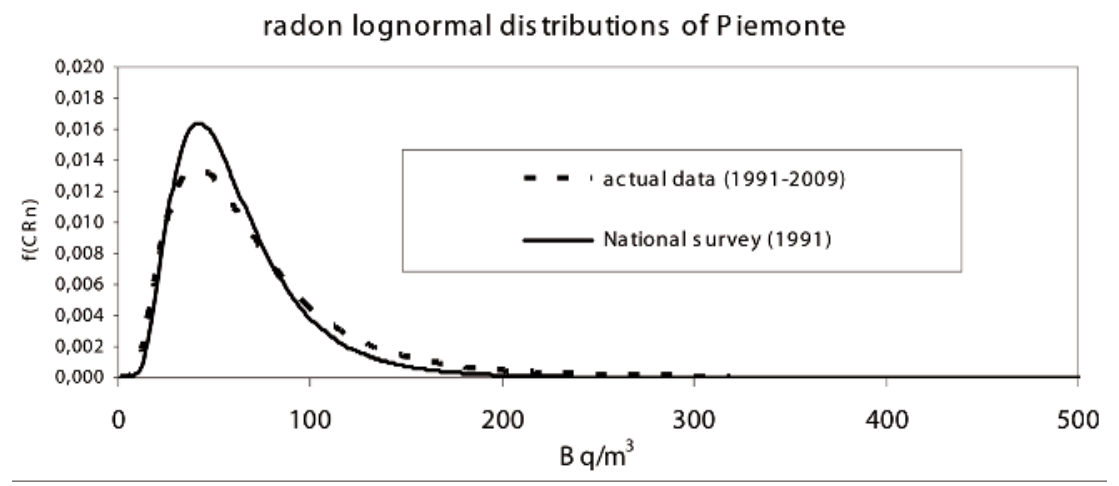

Figure 11: Distribution of the radon concentration in dwellings.

\section{Conclusions}

With the present work it was possible to estimate the average radon levels in each of the 1206 municipalities of Piemonte (fig. 9), more interestingly, to assess the percentage of the population exposed above a given radon concentration (fig. 10), and to define the radon prone areas of the Region, an important achievement in order to evaluate the possible health effects for the population. The overall results (Regional arithmetic mean $=71 \mathrm{~Bq} \mathrm{~m}^{-3}$ ) were also in good agreement (fig. 11) with those obtained in the first radon survey (National survey: $69 \mathrm{~Bq} \mathrm{~m}^{-3}$ ), performed in 1991 with a limited sampling program (430 dwellings).

\section{Acknowledgements}

We are particularly grateful to Paolo Tonanzi, Alessandra Troglia, Marina Zerbato, Anselmo Cucchi and Paolo Falletti (ARPA Piemonte) for the contribution in the geological studies, radon surveys and for the helpful comments and suggestions. We also thank Stefano Bertino, Rosa Maria Tripodi, Maura Ghione, Brunella Bellotto, and Giuliana Garbarino (ARPA Piemonte) for gamma spectrometry measurements.

\section{References}

L. TOMMASINO et al., Plastic-bag sampler for passive radon monitoring, Nuclear Tracks, Vol. 12; 1986. 
ISS, I rivelatori a tracce nucleari per la misura della concentrazione di radon in aria: analisi critica ed esperienze italiane a confronto, Roma 2001.

S. DARBY et al., Radon in homes and risk of lung cancer: collaborative analysis of individual data from 13 European case-control studies, BMJ Volume 330; 2005.

F. BOCHICCHIO, Radon epidemiology and nuclear track detectors: methods, results and perspectives, Radiation Measurements Vol. 40, pp. 177190; 2005.

F. BOCHICCHIO et al., Annual average and seasonal variations of residential radon concentration for all the Italian Regions, Radiation Measurements, Vol. 40, pp. 686-694; 2005.

WHO-IARC. Monograph on the Evaluation of Carcinogenic Risks to Humans: Man-made mineral fibres and Radon. IARC Monograph Vol. 43, Lyon, France; 1988.

WHO Handbook on indoor radon - A public health perspective. WHO 2009.

M. MAGNONI and S. TOFANI, Indoor radon measurements in anomalous sites of Piedmont, Italy, Radiation Protection Dosimetry, Vol. 56, pp. 327$329 ; 1994$.

Regione Veneto - ARPAV. Indagine regionale per l'individuazione delle aree ad alto potenziale radon nel territorio Veneto, Rapporto tecnico ARPAV; 2000.

P.N. PRICE et al., Bayesian prediction of mean indoor radon concentrations for Minnesota counties. Health Phys. 71(6):922-936; 1996.

P.N. PRICE, Predictions and maps of country mean indoor radon concentrations in the mid-atlantic states, Health Phys. 72(6):893-906; 1997.

LSP-Sezione Fisica USSL $n^{\circ} 40$ Ivrea. Indagine sull'esposizione alla radioattività naturale nelle abitazioni del Piemonte, Regione Piemonte; 1994.

ISS-ANPA. Indagine nazionale sulla radioattività naturale nelle abitazioni, ISTISAN Congressi 34; 1994.

F. Bochicchio et al., Areas with high radon levels in Italy, Proceedings of the Conference Radon in the Living Environment, 19-23 April 1999, Athens, Greece. 
F. BOCHICCHIO et al., Results of the representative Italian national survey on radon indoors. Health Phys. 71(5):741-748; 1996.

M. MAGNONI et al., La misura dell ${ }^{238} \mathrm{U}$ mediante spettrometria gamma in matrici ambientali, Convegno Nazionale AIRP-Pisa; 2008.

E. CHIABERTO et al., "Il radon in Piemonte. Dalla distribuzione delle concentrazioni alla definizione delle aree a rischio: criteri a confronto"; Proceedings of the AIRP Conference; Torino 2006.

ARPA Piemonte. La mappatura del radon in Piemonte. 2009; www.arpa. piemonte.it.

J. MILES and K.BALL, Mapping radon-prone areas house radon data and geological boundaries, Environ. Int. 22 (1996) S779-S782.

J. MILES, Development of maps of radon-prone areas using radon measurements in houses. 1998 NRPB - Pub. Elsevier Science.

P. BOSSEW, G. DUBOIS, T. TOLLEFSEN, Investigatios on indoor Radon in Austria, part 2: Geological classes as categorical external drift for spatial modelling of the Radon potential. Journal of Env. Radioactivity 99; 2008.

J. MILES and D. APPLETON, Mapping variation in radon potential both between and within geological units. Journal Radiation Protection 25; 2005 .

L.C.S. GUNDERSEN and R.R. SCHUMANN, Mapping the radon potential of the united states: examples from the Appalachians. Environmental International Vol. 22 pp. S829-S837; 1996.

EPA map of radon zones; www.epa.it. 